\title{
IZSÁK ÉVA: A HAZAI GEOGRÁFIA ELSŐ PhD. ÉRTEKEZÉSÉNEK VÉDÉSE
}

\section{BERNEK ÁGNES}

Izsák Éva, az Eötvös Loránd Tudományegyetem Regionális Földrajzi Tanszékének tanársegédje 1998. május 5-én védte meg "A természeti és társadalmi környezet hatása Budapest határmenti területeinek fejlödésére" c. PhD. értekezését az MTA Földrajztudományi Kutatóintézetében. A nyilvános vita résztvevóinek tekintélyes száma egyrészt a témakör rendkívüli aktualitásának volt köszönhetö, másrészt annak, hogy a hazai földrajztudományban Izsák Éva az első doktorandusz, akinek PhD. értekezését nyilvános vitára tüzték ki. A bíráló bizottság elnöke Márton Péter Professzor Úr, az ELTE Földtudományi Doktori Programjának vezetöje volt; tagjai Klinghammer István, Perczel György, R. Várkonyi Ágnes és Marosi Sándor professzorok voltak. Az értekezést opponálták Berényi István és Bora Gyula professzor urak.

A jelölt öt évet átfogó tudományos munkájának eredményeit foglalta őssze értekezésében. Legfőbb kutatási kérdései a következők voltak:

- Van-e összefüggés a város fejlödése, valamint a természeti és a társadalmi környezet területi eltérései között?

- Milyen hatást gyakorol a természeti kömyezet a város térbeniségére?

- Az eltérő terủleti fejlödés milyen kapcsolatban van a kialakuló társadalmi környezettel?

A disszertáció első két fejezete a természeti és társadalmi kơmyezet hatását elemezte Budapest és környékének fejlődésére. A következő rész a föváros közigazgatási határán belüli és kívüli kerületeket és településeket hasonlította össze bizonyos mutatók alapján, mintaterületeket kiválasztva. Az utolsó fejezet az 1990 óta végbement változásokkal, az agglomerációs övezet településeinek erösen differenciált fejlödésével foglalkozott. Az értekezés összegzéssel, föbb megállapításokkal és következtetésekkel zárult.

$\mathrm{Az}$ opponensek egybehangzó véleménye alapján Izsák Éva disszertációjának legfontosabb tudományos eredményei a következők:

1. A természeti környezet városszerkezetre gyakorolt hatása közvetlen, mert a tagolt térszín meghatározó szerepet játszik a sokgócú térbeniség kialakulásában.

2. Ahol a természeti kömyezetnek elöbbi korlátozó hatása nem érvényesül, ott a funkcionális "térszervező" erö lép elö, s meghatározóvá válik a centrumtól való távolság.

3. A város horizontális terjeszkedésének típusa és a népességnövekedés között szoros kapcsolat van, a természeti tényezök és a centrumtól való távolság befolyásoló hatásai szerint.

4. Az élettér-típusok faktoranalizissel történő lehatárolása alapján a városi tér és a társadalmi tér új összefüggése kővethető nyomon. 
Az opponensek által felvetett kritikai megjegyzések egyben a védésen, mint vitatémák is szerepeltek. Ezek közül igen érdekes volt Bora Professzor Úr felvetése az ingatlanárak városfejlődésre gyakorolt hatását illetöen. Másik kiemelt vitakörhöz a tipizálási és a generalizálási szempontok kiválasztása, illetve az ezek alapján levonható következtetések elméleti kérdöjelei sorolhatók.

A kutatási módszerek közül mind az opponensek, mind a bíráló bizottság tagjai kiemelték az ún. szuburbanizációs indexet. A jelölt a legújabb kutatásai alapján készuilt, disszertációjában még nem szereplö indexmutatókat is bemutatta, illetve elemezte.

Izsák Éva a PhD. fokozatot - disszertációjának színvonala, vizsgái eredménye illetve a nyilvános vita értékelése alapján összesítve - "summa cum laude" minősitéssel szerezte meg.

E rövid ismertetỏ zárásaként, a vita minden résztvevöjének egybehangzó véleményét szeretném tolmácsolni Izsák Évának, nevezetesen további nagyon sikeres, eredményekben gazdag kutatói életpályát kivánunk! 